\title{
Retraction: Computational fluid dynamics in the numerical simulation analysis of end-to-side anastomosis for coarctation of the aorta
}

\author{
Fang Yang ${ }^{1}$, Bo Zhai ${ }^{1}$, Li-Gong Hou ${ }^{2}$, Qian Zhang ${ }^{3}$, Jie Wang ${ }^{3}$ \\ ${ }^{1}$ Department of Cardiac Surgery, Henan Children's Hospital, Zhengzhou Children's Hospital, Zhengzhou, China; ${ }^{2}$ Department of Teaching, Henan \\ Children's Hospital, Zhengzhou Children's Hospital, Zhengzhou, China; ${ }^{3}$ Department of Surgery, Henan Children's Hospital, Zhengzhou Children's \\ Hospital, Zhengzhou, China \\ Correspondence to: Jie Wang. Department of surgery, Henan Children's Hospital, Zhengzhou Children's Hospital, No. 33 of Waihuan Road, \\ Zhengdong New District, Zhengzhou 450018, China. Email: jiewang_dr@163.com.
}

doi: $10.21037 /$ jtd-2021-14

View this article at: http://dx.doi.org/10.21037/jtd-2021-14

Retraction to: J Thorac Dis 2018;10:6578-84.

Recently, we found that the paper entitled "Computational fluid dynamics in the numerical simulation analysis of end-toside anastomosis for coarctation of the aorta" (1) published in the Vol 10, No 12 (December 2018) issue of Fournal of Thoracic Disease is actually a plagiarism of "Hemodynamic Analysis of Surgical Correction for Patient-specific Aortic Coarctation with Aortic Arch Hypoplasia by End-to-side Anastomosis" published on the 2014 7th International Conference on BioMedical Engineering and Informatics. In order to correct this serious mistake, after discussion, all authors agree to retract this paper and understand and appreciate the journal's retraction policy.

\section{Footnote}

Conflicts of Interest: All authors have completed the ICMJE uniform disclosure form (available at http://dx.doi.org/10.21037/ jtd-2021-14). The authors have no conflicts of interest to declare.

Ethical Statement: The author(s) is/are accountable for all aspects of the work in ensuring that questions related to the accuracy or integrity of any part of the work are appropriately investigated and resolved.

Open Access Statement: This is an Open Access article distributed in accordance with the Creative Commons AttributionNonCommercial-NoDerivs 4.0 International License (CC BY-NC-ND 4.0), which permits the non-commercial replication and distribution of the article with the strict proviso that no changes or edits are made and the original work is properly cited (including links to both the formal publication through the relevant DOI and the license). See: https://creativecommons.org/licenses/by-nc-nd/4.0/.

\section{References}

1. Yang F, Zhai B, Hou LG, et al. Computational fluid dynamics in the numerical simulation analysis of end-to-side anastomosis for coarctation of the aorta. J Thorac Dis 2018;10:6578-84.

Cite this article as: Yang F, Zhai B, Hou LG, Zhang Q, Wang J. Retraction: Computational fluid dynamics in the numerical simulation analysis of end-to-side anastomosis for coarctation of the aorta. J Thorac Dis 2021;13(3):2080. doi: 10.21037/jtd-2021-14 